\title{
Rebalancing Quality Education in a Democratic Society
}

\author{
Amy T. Belcastro \\ Southern Oregon University, Ashland, USA \\ Email: belcasta@sou.edu
}

Received 2 March 2015; accepted 20 March 2015; published 24 March 2015

Copyright (c) 2015 by author and Scientific Research Publishing Inc.

This work is licensed under the Creative Commons Attribution International License (CC BY). http://creativecommons.org/licenses/by/4.0/

(c) (i) Open Access

\section{Abstract}

The integrity of democracy and quality education in the United States has been jeopardized by a market-based school reform agenda. The last twenty years of federal policy and legislation has resulted in privatizing public education, vilifying the voices of teachers and narrowing the curriculum to easily quantified skills in reading and math. The curriculum taught in U.S. public schools has been reduced to corporate terms of achievement and measurement. Within this paper, I explored the question, "What does quality education look like in a democracy?" A critique of recent educational reforms in the United States and influential international benchmarks are presented, and a curricular scope for quality education is proposed incorporating the missing democratic fundamentals. This paper hopes to encourage a global dialogue among policy makers, educators and other stakeholders who value a quality public education and see it as necessary to pursue a democratic vision.

\section{Keywords}

Quality Education, Democracy, International Benchmarks, Curricular and System Reform

\section{Introduction}

Quality education is a top priority for any society that values a democracy; at the foundation of democracy lays the symbiotic relationship between quality public education and a robust democratic society (Dewey, 1963; Greene, 1986; Meier, 2000; Parker, 2006; Tocqueville, 1862). However, the terms democracy and quality education are not only ambiguous in their meanings but also, as advocates for democracy argue, the imbalance of private interests over the common good further erodes these meanings (Giroux, 2006; Postman, 1995; Shapiro \& Purpel, 2005).

What is democracy and what does it mean to provide quality education in a democratic society? Democracy 
and quality education are widely used in rhetoric and are often unquestioned by stakeholders and institutions that make claims to these terms. Dahl (1989: p. 21) warned, "A term that means anything means nothing". Today, many educational reform efforts' missions or purpose statements claim to promote quality education and democracy (Apple, 2014; Bowles, 2014; Maxcy, 1995). The purpose and meaning of quality education and democracy are often vague and overshadowed by the principles of the market economy, resulting in what some argue is an anti-democratic structure of schooling (Cochran-Smith \& Fries, 2002; Giroux, 2006; Goodlad, Soder, \& Sirotnik, 1990; Greene, 1998; Meier, 1997).

In this paper I discuss the relationship between quality education and democracy, with the guidance of three essential questions: a) What is the purpose of quality education in a democracy? b) What knowledge is most worth knowing in a democratic society? c) Whom should schools serve in a democracy? A critique of recent educational reforms in the United States and influential international benchmarks is presented, and a new approach of curriculum is proposed, incorporating the missing democratic fundamentals necessary to pursue fully a democratic vision.

\section{Theoretical Framework}

The theoretical framework for this article is informed by Dewey's $(1963 ; 1997)$ philosophical oeuvre, which makes clear that direct engagement in school and society is at the core of a democracy and that citizenry around service to the common good and the general welfare are virtues that transcend beyond a definition of government. "The object and reward of learning is continued capacity for growth" (Dewey, 1997: p. 21). For all members of society, in order to have the opportunity to expand their capacities for growth, they would have to live and be engaged in a democratic society. Dewey's belief about quality education stressed the balance between moral, personal, and civic engagement and emphasized the direct relationship between quality education and a healthy democracy.

Particularly is Dewey's $(1963 ; 1997)$ understanding of the integrity between the means and ends in education and critical curriculum theory (Greene, 1986; Henderson \& Kesson, 2004; Walker, 2003) that intricately links curricular means and educational ends. It is my belief that the principles of democracy must become the educational outcomes of a quality education in democracy. If we want democratic citizens, then our students must have the opportunity in schools to learn democratic principles (Parker, 2006). For example, civic engagement is a democratic principle and therefore evidence of civic engagement must be explicit in educational policies, school organization, and curriculum.

\section{Inquiry into Purpose of Quality Education in a Democracy}

Providing every child with equal opportunity to engage in society and fulfill his or her potential is the definition of quality education in a democratic society. Specifically, quality education in a democracy prepares students to engage positively in their personal lives; be responsible members of society that engage socially; provide the knowledge and skills necessary to engage critically within the disciplines; fulfill their full economic potentials; and prepare citizens to engage in the democratic process and its principles. Failure to secure quality education opportunities for all children, results in the basic principles of democracy unrealized. Any nation who professes democracy, efforts to improve schooling must begin by bringing democratic principles back into the dialogue of quality education.

\section{Guiding Democratic Principles}

The concept of democracy has a long and complex history with many different meanings. A single definition of the ideal of democracy has been widely debated with no resolution. Discussions and debates on the purpose and meaning of democracy are key to its survival. When important questions are raised and principles defined, society's institutional policies, such as those that define quality education, are clarified and aligned to support a democracy.

For the purpose of this paper, the concept of democracy is the potential of democracy (Dahl, 1989). Potential democracy is based on the values of, "freedom, human development and the protection and advancement of shared human interests" (p. 311). This idea of democracy assumed three key principles of equality: moral, personal and civic. Moral equality is the belief that all human beings are equally worthy, regardless of the context 
and removed from the competitive concept of merit as valued by capitalism (Rothblatt, 2007). This concept of individual worth is essential to a potential democracy in that it provides a broader commitment to equality, supporting the ideals of social justice. This principle has important implications in defining quality education in a democracy. Whom should schools serve in a democracy?

Moral issues greatly influence Dahl's second and third principles, personal and civic equality. Challenges that face society at the personal or civic levels are inseparable from the moral values that surround them. Consider the historical issues of civil rights such as the right to vote, the right to marry, and the right to an education. These civic equalities require a belief in moral equality. For example, women, people of color and the gay and lesbian community must be equally worthy in order to achieve the personal and civic equality required for a democracy. The moral beliefs and values of a society are the foundation in which the level of personal and civic equality is determined.

Personal equality is the right to self-determination "expressed by the presumption that adult persons are entitled to personal autonomy in determining what is best for themselves" (Dahl, 1989: p. 311). This principle underscores the responsibilities of preparing citizens to be able to engage positively in their personal lives and reach their full economic potentials, not limited by "otherness" such as gender, race, or sexuality. By providing the essential knowledge and skills necessary to engage critically within the disciplines students will be better prepared to solve society and institutional problems that prevent personal equality.

The principle of civic equality is the right to political self-determination, embodying the political and legal rights promised to all citizens as listed in many democratic constitutions throughout the world. The criteria and the right to engage in the democratic process often define civic equality. Therefore, it is my position that in order for civic equality to exist in a democracy, there must be support for moral and personal levels of democracy. This point highlights the need for quality education that prepares citizens for engaging in the democratic process and principles at a civic, moral and personal level. Unfortunately, the basic principle of civic equality is lacking in educational experience from many citizens' of a democracy (Hargreaves, 2010; Parker, 2006; UNICEF, 2013). Inclusion of moral and personal aspects of quality education is critical if there is to be a continuing symbiotic relationship between quality education and a robust democratic society.

The idea of maintaining and supporting democracy as a process is not new. From the beginning, advocates for democracy have reasoned that direct engagement in a democracy was fundamental to its survival (Dahl, 1989; Dewey, 1963, 1997; Meire, 2000; Tocqueville, 1862). These authors warned against passivism, over-dependence on the government, and forfeiture of the liberties and freedoms of the individual. We see examples of these in warnings playing out in school's policies, curriculum, and funding models. They also saw moral and personal equalities as essential, arguing that individuals must be actively engaged in both the common good and private interest for a democracy to survive. Finally, they believed that quality education was necessary for all citizens in order to prevent a democracy from becoming a guardianship and contended that the democratic process must remain in the hands of its citizens not given over to a controlling federal government or market system.

\section{Findings: What Is Influencing Education Reform in the U.S. and Beyond?}

What follows is a discussion about the implications and challenges presented by the imbalanced market-model ideology's influence on educational policies with the focus being on the federal government in the United States. Specifically, the revisions of the elementary and secondary education act (ESEA), and the proposal to replace No Child Left Behind (NCLB) with Race To The Top (RTTT) are damaging educational reform. Through this discussion, I explore how the two educational reforms have dismantled public education's curriculum and resources in the U.S. and discuss international similarities and associations. This section addresses two questions: a) When ignoring the principles of democracy, what implications emerge? b) Who is being served by society and who is being left behind?

In 2002, President G. W. Bush reauthorized the Elementary and Secondary Education Act of 1965 as the No Child Left Behind Act (NCLB, 2001). This Act outlined a quality education based on the values of the presidential administration. As an educational reform effort, NCLB sought to promote democracy by ensuring "all schools" and "all students" met the same academic standards. Unfortunately, the NCLB Act put into policy a narrow epistemological view, often limited to basic skill and content attainment with little to no content engagement or purpose for applying the knowledge (Darling-Hammond \& Sikes, 2004; Meier, 2000). The academic standards and valued knowledge used to define quality education under the NCLB Act did not promote democ- 
racy, but instead supported an imbalanced vision of democracy with the purpose to advance social mobility and the principles of capitalism.

Under President Obama, the U.S. Department of Education (2009) enacted the Race To The Top (RTTT) competitive grant program as a part of the American Recovery and Reinvestment Act of 2009. It promised to invest $\$ 4.35$ billion to turn around low-performing schools, increase students' achievement in math and reading to be globally competitive, and ensure students were prepared to enter colleges or the work force. However, there has been great disappointment by many educational stakeholders that RTTT did not fulfill its promise. Former Assistant Secretary of Education Diane Ravitch criticized RTTT saying that, "there is empirical evidence, and it shows clearly that choice, competition and accountability as education reform levers are not working. But with confidence bordering on recklessness, the Obama administration is plunging ahead, pushing an aggressive program of school reform - codified in its signature race to the top program - that relies on the power of incentives and competition" (2010: p. 1).

RTTT relies heavily on compliance and a competition for the $\$ 4.35$ billion of resources. The financial costs of RTTT include items such as: comprehensive data systems for the evaluation of teachers, the development of national common core standards (CCS) in mathematics and language arts, curriculum materials and high-stake national tests that align to the CCS. However, the financial costs of RTTT come at an even greater price, resulting in: the continued narrowing of curriculum that began with NCLB, devaluing and marginalizing the profession of teaching, a de-investment of public schools with a greater investment incharter schools, and a federal curriculumand assessments with a narrow prioritization of STEM (Science, Technology, Engineering, and Math) providing more opportunities for the private sectors to profit (Levin \& Levin, 2012; Ravitch, 2011).

Public education in United States has become a big business. NCLB and RTTT have pushed for: teacher evaluation data systems that remove the voice and professionalism of our teachers, a narrow national curriculum of reading and math which threatens students ability to use these skills in meaningful ways, national high-stake assessments that have created hostile and inhumane learning environments which have reduced student and teacher motivation and performance, and have increased the education market for private interests (Onosko, 2011; Wei, Darling-Hammond, \& Adamson, 2010). The cost of tests, related services and the supplies for 50 million children in 132,000 schools profited the private companies (Levin \& Levin, 2012).

The current U.S. education reforms give renewed meaning to Tocqueville's (1862) warnings against passivism and forfeiting liberties of the individual's moral and personal equalities. One can simply look to the funding models of education, national standards and curriculums, and high stake national assessments imposed on students, teachers and school districts, resulting in the profiteering of corporate American. This threat echoes Dewey's (1916) plea for engagement in society and growth of the person. Education in the United States is at odds with the vision of social justice and core democratic principles and more aligned with the values of private enterprise and the market system and unfortunately, the U.S. is not alone.

There is a global threat for all democratic countries where education reform models have moved to institutional and systemic approaches to "change education on a large scale across entire systems and countries in relation to particular visions of economic reforms" (Hargreaves, 2010: p. 105). Quality education is policy-susceptible which is evident as one looks at the various reform efforts worldwide and the common goal of improving education to strengthen the country.

\subsection{International Influences on Educational Reform}

International benchmarks provide opportunity for international comparisons on student outcomes and educational systems, and have become a globalizing factor, continuing to increase in popularity and use worldwide. Two of examples that are heavily influencing educational policy reform globally are the results of the Programme of International Student Assessment (PISA) and the United Nations Children Fund study on childhood wellness (UNICEF). PISA is a triennial international study of student learning out comes in reading, math and science for 15 year olds. PISA has evolved to serve as a global standard and international benchmark used to compare over 65 countries (Breakspear, 2012). Five dimensions discern the UNICEF study of children's wellness: material, health and safety, education, behaviors and risks, and housing and environment in the world's advance economies (2013). The dimensions of UNICEF provide a look at how countries and polices support their citizens wellness.

An example how these benchmarks are influencing policy is seen by the international reactions to PISA re- 
sults. Across the world, there is a plethora of reports, collaborative efforts to make informed policy decisions, and educational reforms based on the results of PISA. An example is the many variations of "Lessons Learned from PISA", which are country specific analysis done in collaboration with Organization for Economic Co-operation and Development (OECD). In the U.S., it resulted in a collaborative effort between the OECD, the National Center on Education and the Economy, government officials of the case study countries discussed, and international experts in analyzing education performance systems internationally; similar reports and efforts occurred in other countries like Germany, Mexico, Korea, Japan, and Singapore (OECD, 2011).

Although international benchmarks like PISA and UNICEF reports come with global pressures, they also contribute to new ideas and dialogue, pulling countries out of their ethnocentric approaches to reform. These reports have raised questions, highlighted policies, and best practices from high achieving countries and economies like China-Shanghai, China-Hong Kong, Japan, Canada, Germany, Switzerland, and Finland. Some of the most influential and possibility most controversial finding from recent international benchmarks are:

- Students achieve higher if they feel they belong;

- An openness to problem solving shows significantly higher achievement in mathematics as well as engagement, motivation and a positive mindset;

- Teacher-student relationships are significantly associated with student engagement;

- Socio-economically disadvantaged students score lower in academic skills, knowledge and disposition across most countries and economies. Although resilient students, socio-economically disadvantaged students who achieve at high levels share same characteristics of advanced higher achievers;

- Teacher quality, support for teachers' professional development and collaboration, and teacher ownership over curriculum makes a significant difference in student achievement (PISA, 2012; UNICEF, 2013).

These findings are also supported by other key international reports: the McKinsey's 2007 report that explored over 600 reform strategies across 20 school systems worldwide over a period of 25 years, Alliance for Excellent Education, National and Stanford Center for Opportunity Policy in Education.

One example that is creating international dialogue is from the highest performing country in mathematics, Shanghai, China. According to the 2012 PISA results, Shanghai's students believe that they have the locus of control to succeed and that achievement is the result of hard work and persistence not an inherited intelligence. The results showed that a positive mindset greatly contributes to student's overall success and is related to an openness to problem solving, greater intrinsic motivation and more confidence to persistent (PISA, 2012). Other high achieving countries also shared similar dispositions resulting in the following statement from UNICEF to improve education:

Schools can help students learn how to learn, nurture their willingness to solve problems, and build their capacity for hard work and persistence. Teachers can help students to develop perseverance and motivation by supporting students in their efforts to meet high expectations and in showing greater degrees of commitment, and by encouraging students to regard mistakes and setbacks as learning opportunities (2013, p. 22).

These findings encourage teachers to: provide more formative feedback, require students to show their thinking, provide learning opportunities where students are asked to think critically and problem solve over periods of time, and integrate what they are learning (Hargreaves, 2011; Sahlberg, 2010; Wei et al., 2010). According to research on cognition and learning, these strategies have shown to support a positive mindset and improve achievement (Dweck, 2006).

Agents for educational reform around the world are applauding the findings that encourage the intellectual, social, aesthetic and emotional development of students, and supports public schools and teachers as essential in strengthen countries. For example, Tero Henrik Autio, a Professor at Tallinn University in Finland specializing in international curriculum research cautions educational leaders about the relationship between the public good and education, "the succession of the American educational logic from psychology to bureaucratization and, increasingly, to the present form of commodification and privatization instead of conceiving of education as a public good has been spread out across the education world" (2012: p. 22). He further warns of the "neoliberal education doctrines of 'teacher-prove curricular', 'accountability', 'teaching to the test' is just the contrary to many best achieving countries (e.g., Finland and Singapore) in numerous international educational comparisons the same countries perform well on international ratings of economic competitiveness, too" (p. 22).

Another example is, Professor Edmond Law a Professor in Curriculum at the Asia Pacific Centre for Leadership and Change (APCLC) Hong Kong Institute of Education who explained that Asian countries' students are achieving higher in science, mathematics and reading because ancient concepts of learning and pedagogy are being incorporated and valued within modern progressive education such as, "thinking, investigation, authentic 
learning, the experiential nature of learning, self-reflection, application, and a personal attitude toward learning" (2014: p. 224).

These and other change agents are encouraging policy makers to use the lessons learned from higher achieving countries and invest in: the human factor of innovation, creativity, and relationships, the profession of teachers, and the engagement of students in the civic, moral and personal aspects of learning (Autio, 2013; Law, 2014; Pinar, 2014; Wei et al., 2010). These finding have important meanings for democratic values and in particular for issue of social justice. Dewey's belief about quality education stressed the balance between moral, personal, and civic engagement and emphasized the direct relationship between quality education and a healthy democracy.

Dewey $(1963 ; 1997)$ believed that direct engagement in school and society was at the core of a democracy and that citizenry around service to the common good and the general welfare were virtues that transcended beyond a definition of government. "The object and reward of learning is continued capacity for growth" (Dewey, 1997: p. 21). In order for all members of society to have the opportunity to expand their capacities for growth, they would have to live and be engaged in a democratic society.

\subsection{Transmission of Knowledge Leaves U.S. Short}

Market model values of capitalism are reflected in policy decisionsand in the organization of knowledge and learning. Public schools in the U.S. have been encouraged to organize the nature of knowledge around the "transmission of knowledge model" to support market fundamentalism (Darling-Hammond, 2010; Giroux, 2006; Leonardo, 2004; Villegas \& Lucas, 2002). Transmission of knowledge assumes knowledge, determined by experts, is a reality existing outside of the classroom and learner and transmitted by teachers to the passively awaiting students (Banks, 1993; Villegas \& Lucas, 2002). In a democracy, "a quality education encourages students to become aware of, if not work against, social injustices" (Leonardo, 2004: p. 13) versus the marketmodel that relies on social inequities.

Under the NCLB and RTTT legislation the language and values of corporate America became the language and vision of education. Power, competition and privilege gained through the accumulation of capital are the quintessence of capitalism. Capitalism limits the equality principles of a democracy and in fact, generates inequalities in power and resources (Dahl, 1998; Green, 1985). "The inequalities in the distribution of economic capital are virtually reproduced in the distribution of political capital" (Green, 1985: p. 14). Capitalism, by its very nature, allows some substantial gains but limits others and is the antithesis of a democracy. "This rule of privilege is the very essence of capitalism, incompatible with democracy in the strongest sense. The kind of economic and social inequity that contemporary capitalism manifests makes the notion of citizenship a chimera" (Green, 1985: p. 13).

The proposed policy of RTTT replacing NCLB will continue to support the market model vision of education, reducing citizens to consumers and knowledge to a prescribed set of skills and information. As a result, the current purpose of schooling will be to educate consumers in market fundamentalism as opposed to educating citizens in a democracy. This is a critical point in U.S. history and in the international dialogue of quality education.

Under market fundamentalism, "Knowledge is presented as a commodity to be acquired, never as a human struggle to understand, to overcome falsity, to stumble toward the truth" (Postman, 1995: p. 116). This idea of knowledge is reduced to de-contextualized facts and truths, which contain right or wrong answers, and simple ask students to answer the problems presented without encouraging them to question the answers or problem solve. Teaching is also reduced to transmitting prescribed information with the assumption that all students learn the same (Villegas \& Lucas, 2002). This kind of educational experience neither supports learning for understanding, acknowledging the critical role that students play in learning nor prepares citizens for active participation in a democracy.

A quality education could appear hopeless given the aforementioned challenges and the current vision of quality education founded on the imbalanced principles of democracy that serve the private good over the common good. An optimistic critique requires an awareness of reality coupled with the hope and will to make change. Thus, the final section of this paper provides an alternative and offers a language of possibility for rebalancing a quality education in a democracy.

\section{Discussion: An Alternative Vision for Quality Education}

The democratic road is the hard one to take. It is the road, which places the greatest burden of responsibility 
upon the greatest number of human beings. Backsets and deviation occur. However, that which is its own weakness at particular times is its strength in the long course of human history (Dewey, 1997: p. 100).

Dewey's words underscore both the challenge of maintaining a democracy and the optimism needed to do so. The time for the greatest number of human beings to engage in the fight for democracy is not in foreign lands but in their own public schools. This challenge requires citizens to rethink the purpose of education in a democracy, to explore the presence of democratic principles in their educational system, to scrutinize the policies, resources and curriculum, and if necessary to propose an alternative that restores the democratic principles - moral equality, personal equality and civic equality -in the structure of schools.

Deliberations about the purpose of education and the moral implications of a democracy in educating its citizens have characterized society in the United States from its inception to the present. The works of critical theorists (e.g., Paulo Freire, Henry Giroux, Neil Postman, and Maxine Greene) remind us that the potential for change lies in the willingness to examine our problems critically and imagine alternatives. While pragmatists like Dewey ask us to consider the implications that these alternatives might hold.

Dewey saw education not only as preparation for a future life but also as life itself. I have proposed an approach to curriculum that integrates the democratic principles (see Table 1). This curricular scope organizes developmentally the knowledge, skills, and dispositions (KSD) needed for personal, social, and civic engagement, thus intentionally supporting the symbiotic relationship between quality education and a healthy democratic society. The curricular scope does not provide a set of knowledge and skills to be taught at each grade level rather, it offers important developmental ideas and concepts to be considered in decisions regarding policies within curricula.

This curriculum scope, Quality Education for a Democracy, defines quality education in a democracy as one that prepares students to:

1) Engage positively in their personal lives;

2) Become responsible members of society that engage socially;

3) Fulfill their full economic potentials;

4) Become citizens that engage in the democratic process and principles;

5) Use the knowledge and skills necessary to engage critically within the disciplines.

Quality education for a democracy (see Table 1), embodies four fundamental understandings necessary to pursue fully a democratic vision: a) self, which includes self-awareness and personal engagement; b) global, which includes social awareness and social engagement; c) universal, which includes content awareness and concept engagement; d) transformative, which includes civic awareness and civic engagement. Each area of understanding, while essential to the whole, is dependent and relies on the others to build a basic level of awareness that

\section{Table 1. Curriculum scope: quality education for a democracy.}

\begin{tabular}{|c|c|c|c|}
\hline $\begin{array}{c}\text { SELF } \\
\text { KNOWLEDGE }\end{array}$ & GLOBAL KNOWLEDGE & $\begin{array}{l}\text { UNIVERSAL } \\
\text { KNOWLEDGE }\end{array}$ & $\begin{array}{l}\text { TRANSFORMATIVE } \\
\text { KNOWLEDGE }\end{array}$ \\
\hline \begin{tabular}{ll} 
& \multicolumn{1}{c}{ Self-Awareness } \\
- & Emotional awareness \\
- & Personal authenticity \\
- & Self-reflectivity \\
- & Moral consciousness \\
- & Independency \\
- & Adaptability
\end{tabular} & \begin{tabular}{ll} 
& \multicolumn{1}{c}{ Social Awareness } \\
- & Socio-cultural consciousness \\
- & Organizational awareness \\
- & Empathy for others \\
- & Service orientation
\end{tabular} & \begin{tabular}{ll} 
& \multicolumn{1}{c}{ Content Awareness } \\
- & Science \\
- & Social science \\
- & Mathematics \\
- & Humanities \\
- & Arts \\
- & Written and oral communication \\
- & Inquiry, critical, and creative \\
& thinking
\end{tabular} & $\begin{array}{l}\text { Civic Awareness } \\
\text { - } \quad \text { Struggle for democracy \& the } \\
\text { nature of oppression } \\
\text { - } \quad \text { Multiple interactive vantage } \\
\text { points } \\
\text { - Intercultural competencies } \\
\text { - Analysis of interlocking systems }\end{array}$ \\
\hline $\begin{array}{ll} & \text { Personal Engagement } \\
\text { - } & \text { Self-actualization } \\
\text { - } & \text { Ethical reasoning } \\
\text { - } & \text { Integrity } \\
\text { - } & \text { Self-control } \\
\text { - } & \text { Self-confidence } \\
\text { - } & \text { Conscientiousness }\end{array}$ & $\begin{array}{ll} & \text { Social Engagement } \\
\text { - } & \text { Social responsibility } \\
\text { - } & \text { Interdependence } \\
\text { - } & \text { Conflict management } \\
\text { - } & \text { Leadership }\end{array}$ & $\begin{array}{l}\text { Concept Engagement } \\
\text { - Connect ideas from various } \\
\text { disciplines } \\
\text { - Analyze and think critically } \\
\text { within and across the various } \\
\text { disciplines } \\
\text { - Apply the knowledge and skills in } \\
\text { various disciplines to generate } \\
\text { new knowledge }\end{array}$ & $\begin{array}{l}\quad \text { Civic Engagement } \\
\text { - } \text { Justice oriented } \\
\text { - Understand the } \\
\text { interconnectedness } \\
\text { - } \quad \text { Engage in the arts of democracy } \\
\text { - } \text { Allow for a multicultural } \\
\text { philosophy } \\
\text { - Use a critical voice } \\
\text { - } \text { Problem solve } \\
\text { - Change catalyst }\end{array}$ \\
\hline
\end{tabular}


can be developed into a level of engagement. In addition, the scope is organized to honor both the developmental path of the individual, as well as, the sophistication that exists within the master of knowledge and the development of skills and dispositions. The understandings are linear, in that an individual would develop across the framework from self understanding through transformative understanding, while continuing to extend the knowledge, skills and dispositions at the awareness levels to be able to apply them in the engagement levels.

\subsection{Self-Understanding}

An understanding of oneself has been an integral part of formal education from the beginning. The Greeks taught the importance of knowing thyself as a foundation to learning, often referred to as "emotional intelligence" (Goleman, 1995). Emotional intelligence is a form of social intelligence that involves the ability to monitor the feelings and emotions of both one's own and that of others, to discriminate among the feelings and emotions, and to use this information to guide one's thoughts and actions (Mayer \& Salovey, 1997). Research suggests that emotional intelligence is directly related to success in learning, in that the intellect and emotion in learning are inseparable (Elisa et al., 1997; Lazarus, 2000). Emotional intelligence is essential for the successful development of cognitive thinking and learning skills.

Self-awareness is foundational in the developmental process of becoming a citizen capable of engaging in and supporting democratic principles such as social justice. It encompasses the knowledge, skills, and dispositions (KSD) necessary to become conscious of who we are, what we feel and believe, what we can accomplish, and what we can change. In order to support the development of self-awareness, schools need to attend to the individual's own levels of development in the areas of emotional awareness, personal authenticity, self-reflectivity, moral consciousness, independency, and adaptability. Together, these areas provide a foundation that allows the individual to develop a level of self-awareness into personal engagement. The outcomes of personal engagement make up the KSD necessary for individuals to be able to engage positively in their own personal lives, an essential aspect of a democratic society. Citizens are often required to make difficult moral decisions in order to maintain the principles of democratic and civic equality. These moral decisions are not possible without a strong knowledge of self.

In order to develop an understanding of the self, educators will need to begin with the emotional and social needs of students, provide guided instruction and opportunities to develop such KSD that contribute to personal engagement. Fortunately a movement exists to promote the social and emotional learning in schools through curriculum design, professional development, and restructuring of schools (Cohen, 1999; Elias et al., 1998). Organizations such as the Project for Social and Emotional Learning and the Collaborative for Advancement of Social and Emotional Learning have spearheaded the social and emotional learning movement. The Association for Supervision and Curriculum Development set forth the first empirically supported Guideline for Promoting Social and Emotional Learning stating:

As children grow and face situations of increasing complexity and challenge, it is beneficial to provide a developmentally appropriate combination of formal, curriculum-based instruction with ongoing informal, and infused opportunities to develop social and emotional skills from preschool through high school (Elias et al., 1998: p. 33).

\subsection{Global Understanding}

Global understanding is essential for an individual to become a responsible member of a democratic society. It supports the key principle of moral equality, including the ideals of social justice, and prepares citizens to make the challenging moral decisions necessary to engage in democratic equality. Global understanding is comprised of two sub-categories: social awareness and social engagement, together, they make up the foundational KSDto protect both the private and common good (Colby, Ehrlich, Beaumont, \& Stephens, 2003; Shapiro \& Purpel, 2005), which is further developed under transformative understanding.

The developmental organization of self-understanding to global understanding is supported by the literature and theory of Social Emotional Intelligence (Bar-On, 2005; Goleman, 2001; Mayer \& Salovey, 1997). Global understanding is an extension of self understanding in that a student must first understand him or herself before he or she can understand another (Bar-On, 2005; Goleman, 2001). Unfortunately, efforts taking place in education to promote global knowledge including multicultural education (Banks, 1993; Gay \& Howard, 2000), culturally responsive teaching (Cochran-Smith, 1995; Villegas \& Lucas, 2002), teaching for social justice 
(Cochran-Smith, 2004; Meier, 1997; Meier, 2000), and moral education (Feinber, 1990; Frenstermacher, 1990; Goodlad, Soder, \& Sirotnik, 1990; Nodding, 1984) are not supported with policy or resources. These efforts are critical in attaining balance between the private good and the common good.

Global understanding provides another part of the necessary knowledge, skills and dispositions needed to balance our democracy. This understanding is more important than ever, as global interdependence grows rapidly with the complexities of contemporary society and our own democracy become further imbalanced by a lack of attention to the common good. Global understanding is necessary to put the common good back into the school curriculum. The importance of becoming aware and understanding of oneself and other (self understanding and global understanding) allows the individual to see him or herself as part of a larger collective and is essential in supporting the principles of democratic equality and engage in the social justice processes needed for democratic citizenship (Dahl, 1989). This vision of self is critical if individuals are to have any ownership of the social, political and economic problems that face our society and therefore, the responsibility for engaging in and resolving them.

\subsection{Universal Understanding}

Presently, curriculum in U.S. public schools almost exclusively focuses on content awareness as a result of the educational reform efforts of NCLB and RTTT. Student success has been reduced to a score on a standardized test that focus primarily on content awareness (basic literacy, numeracy, information literacy and general literacy in the various fields of study). The vision of quality education in the United States has resulted in a narrowing of curriculum, a transmission of knowledge, and de-contextualization of skills. This over-emphasis on content awareness, with a focus on two subject areas, at the exclusion of all other levels of awareness and engagement threatens both the principles of democracy and ironically the economic goals of the U.S., supported by NCLB and RTTT. Students who cannot think critically, creatively, or globally cannot solve new problems, create new ideas or form new knowledge. Recent studies looking at the work force and employee readiness in the U.S. (e.g., Adecco's 2013 State of the Economy and Employment Survey and CBIA's 2013 Hartford-Springfield Business Survey) have shown a serious lack of "professional/soft skills" such as critical thinking, creativity, collaboration, interpersonal skills, leadership ability, and work ethic. This problem threatens the economic opportunities and future of the U.S. and limits the individual's full potential for development. Expanding what is taught, assessed and valued in public schools are essential if citizens are to achieve moral, personal and civic equality.

Schools are at risk of becoming institutions responsible for creating consumers not citizens who can engage at a deeper level with the academic content or as Goodlad (2004) described, having necessary knowledge and skills within the academic disciplines needed to enter the human conversation. In order to achieve this, educators must help students contextualize the academic disciplines within themselves and others while providing a clear purpose for engaging within the disciplines in meaningful and new ways (Bruner, 1960; Dewey, 1933; Wiggins et. al, 1998).

\subsection{Transformative Understanding}

Transformative understanding represents the knowledge, skills and dispositions needed engage in the democratic principle of civic equality. These educational outcomes of civic equality are supported through the development self-understanding, global understanding and universal understanding. When these understandings are collectively and intentional taught, they allow for the development of the democratic principles. To achieve this ideal, educators must prepare students to use their KSD rather than simply acquire them. Transformative understanding is a necessary part of balancing the means and ends of an education that prepares citizens for engaging in the democratic process and principles at a civic, moral and personal level.

At the awareness level of transformative understanding is the development of essential civic knowledge, which includes the awareness of: the struggles for democracy, the nature of oppression, multiple interactive vantage points, intercultural competencies, and an analysis of interlocking systems. Civic engagement is the most complex and sophisticated application of knowledge building on the understandings of self, other and the academic disciplines to fully understand and engage. The educational outcomes of civic engagement (justice oriented, interconnectedness, acts of democracy, global thinking and engagement, critical voice, problem finding, and alternative solution thinking) support both a democracy and symbiotic relationship between quality education and democracy. 


\section{Conclusion}

Quality education can only exist in a democracy when public schools model the democratic principles and provide every child an equal opportunity to engage in them. The integrity of democracy and quality education in the United States has been jeopardized due to the increased federal control, over standardization and emphasized market-based approach. Americans must challenge the prevailing fundamentalism of government and intervene on their own behalves against a redesign of the elementary and secondary education Act that based on the flawed act of NCLB and Race To The Top. As a nation that semantically advocates for democracy, it must start by putting meaning and purpose back in to democracy and with that revive the symbiotic relationship between a robust democracy and quality public education.

I implore all stakeholders in a democracy to re-think the fundamental meaning of democracy and the symbiotic relationship between democracy and public schools. As Albert Einstein stated after the discovery of atomic fission, "everything has changed except the way we think". The idle way of thinking about education in a democracy needs challenging by all educators, researchers, and policymakers if there is to be realization of a democratic vision.

It is my hope that the curricular scope, quality education in a democracy (see Table 1), can be use to extend the dialogue on quality education to include the knowledge necessary for effective democratic citizenry. This approach to education highlights what Parker (2005) argued is, "a proper curriculum for democracy requires both the study and the practice of democracy" (p. 351). Children must have opportunities to develop the knowledge and skills to engage positively in their own personal lives. They should be encouraged to consider issues on a moral and civic level and to ask why or why not. Every child must have the freedom to engage critically in the human conversation and to seek out the problems that limit and extend our potential as individuals and a nation.

\section{References}

Apple, M. W. (2014). Official Knowledge: Democratic Education in a Conservative Age. New York: Routledge.

Autio, T. (2013). The Internationalization of Curriculum Research. In W. F. Pinar (Ed.), International Handbook of Curriculum Research (2nd ed., pp. 17-31). New York: Routledge.

Banks, J. (1993). The Canon Debate, Knowledge Construction and Multicultural Education. Educational Researcher, 22, 414. http://dx.doi.org/10.3102/0013189X022005004

Bowles, S. (2014). Schooling in Capitalist America: Educational Reform and the Contradictions of Economic Life. Chicago and New York: Haymarket Books.

Breakspear, S. (2012). The Policy Impact of PISA: An Exploration of the Normative Effects of International Benchmarking in School System Performance. OECD Education Working Papers, No. 71, New York: OECD. http://dx.doi.org/10.1787/5k9fdfaffr28-en

Bruner, J. (1960). The Process of Education. Cambridge, MA: Harvard University Press.

Cochran-Smith, M. (1995). Uncertain Allies: Understanding the Boundaries between Race and Teaching. Harvard Educational Review, 56, 541-570.

Cochran-Smith, M. (2004). Walking the Road: Race, Diversity, and Social Justice in Teacher Education. New York, NY: Teachers College Press.

Cochran-Smith, M., \& Fries, M. K. (2002). The Discourse of Reform in Teacher Education: Extending the Dialogue. Educational Researcher, 31, 26-29. http://dx.doi.org/10.3102/0013189X031006026

Cohen, J. (1999). Educating Minds and Hearts. New York, NY: Teachers College Press.

Colby, A., Ehrlich, T., Beaumont, E., \& Stephens, J. (2003). Educating Citizens: Preparing American's Undergraduates for Lives of Moral and Civic Responsibility. San Francisco, CA: Jossey Bass.

Dahl, R. (1989). Democracy and Its Critics. New Haven, MA: Yale University Press.

Darling-Hammond, L., \& Sikes, G. (2004). A Teacher Supply Policy for Education: How to Meet the "Highly Qualified Teacher" Challenge. In N. Epstein (Ed.), Who's in Charge Here? Washington, DC: Brookings Institution Press.

Dewey, J. (1916/1997). Democracy and Education. New York: The Free Press.

Dewey, J. (1933). How We Think: A Restatement of the Relation of Reflective Thinking to the Educative Process. Boston, MA: Henry Holt.

Dewey, J. (1938/1963). Experience and Education. New York: Simon \& Schuster. 
Dweck, C. (2006). Mindset: The New Psychology of Success. New York: Random House LLC.

Elias, M., Zins, J., Weissberg, R., Frey, K., Greenberg, M., Haynes, N., Kessler, R., \& Freire, P. (1998). Pedagogy of Freedom: Ethics, Democracy, and Civic Courage. Lanham, MD: Rowman and Littlefield.

Giroux, H. (2006). Dirty Democracy and State Terrorism: The Politics of the New Authoritarianism in the United States. Comparative Studies of South Asia, Africa and the Middle East, 26, 163-177. http://dx.doi.org/10.1215/1089201x-2006-001

Goleman, D. (1995). Emotional Intelligence. New York: Bantam.

Goleman, D. (2001). An EI-Based Theory of Performance. In C. Cherniss, \& D. Goleman (Eds.), The Emotionally Intelligent Workplace (pp. 27-44). San Francisco, CA: Jossey-Bass.

Goodlad, J., Mantle-Bromley, C., \& Goodlad, S. (2004). Education for Everyone: Agenda for Education in a Democracy. San Francisco, CA: Jossey-Bass.

Goodlad, J., Soder, R., \& Sirotnik, K. (1990). The Moral Dimensions of Teaching. San Francisco, CA: Jossey-Bass.

Green, P. (1985). Retrieving Democracy: In Search of Civic Equality. London: Methuen.

Greene, M. (1986). In Search of Critical Pedagogy. Harvard Educational Review, 56, 427-441.

Greene, M. (1998). Preface. In W. Ayers, J. Hunt, \& T. Quinn (Eds.), Teaching for Social Justice. New York: Teachers College Press.

Hargreaves, A. (2011). Change from Without: Lessons from Other Countries, Systems, and Sectors. In A. Hargreaves, A. Lieberman, M. Fullan, \& D. Hopkins (Eds.), Second International Handbook of Educational Change (pp. 611-629). Dordrecht: Springer.

Henderson, J., \& Kesson, K. (2004). Curriculum Wisdom: Educational Decisions in Democratic Societies. Upper Saddle River, NJ: Pearson Education.

Law, E. H. F. (2014). In Search of a Diverse Curriculum: Toward the Making of a Postmodern Hong Kong in the 21st Century. In W. Pinar (Ed.), International Handbook of Curriculum Research (2nd ed., pp. 217-226). New York: Routledge.

Leonardo, Z. (2004). Critical Social Theory and Transformative Knowledge: The Functions of Criticism in Quality Education. American Research Education Association, 33, 11-18.

Maxcy, J. (1995). Democracy, Chaos, and the New School Order. Thousand Oaks, CA: Corwin Press.

Meier, D. (2000). Educating a Democracy. Boston Review, Champaign, IL: University of Illinois Press.

No Child Left Behind Act (2001). P.L. 107-102, Title I, Section 1111(2)(A).

Nodding, N. (1984). Caring: A Feminine Approach to Ethics and Moral Education. Berkeley, CA: University of California Press.

OECD (2011). Strong Performers and Successful Reformers in Education: Lessons from PISA for the United States. Paris: OECD Publishing. http://dx.doi.org/10.1787/9789264096660-en

Onosko, J. (2011). Race to the Top Leaves Children and Future Citizens behind: The Devastating Effects of Centralization, Standardization, and High Stakes Accountability. Democracy and Education, 19, 1-11.

Parker, W. (2006). Public Discourses in Schools: Purposes, Problems, Possibilities. Educational Researcher, 35, 11-18. http://dx.doi.org/10.3102/0013189X035008011

Postman, N. (1995). The End of Education. New York: Alfred A. Knopf.

Ravitch, D. (2011). Obama's Race to the Top Will Not Improve Education. Huffington Post. http://www.huffingtonpost.com/diane-ravitch/obamas-race-to-the-top-wi b 666598.html

Rothblatt, S. (2007). Education's Abiding Moral Dilemma: Merit and Worth in the Cross-Atlantic Democracies, $1800-2006$. Didcot: Symposium Books.

Sahlberg, P. (2010). Rethinking Accountability in a Knowledge Society. Journal of Educational Change, 11, 45-61. http://dx.doi.org/10.1007/s10833-008-9098-2

Shapiro, H., \& Purpel, D. (2005). Critical Social Issues in American Education: Democracy and Meaning in a Globalizing World (3rd ed.). Mahwah, NJ: Lawrence Erlbaum.

Tocqueville, A. (1862). Democracy in America and Two Essays on America. London: Longman, Green, Longman, and Roberts.

UNICEF Office of Research (2013). Child Well-Being in Rich Countries: A Comparative Overview. Innocenti Report Card 11, Florence: UNICEF Office of Research.

US Department of Education (USED) (2009). Race to the Top Program: Executive Summary. http://www2.ed.gov/programs/racetothetop/executive-summary.pdf 
Villegas, A., \& Lucas, T. (2002). Educating Culturally Responsible Teachers. Albany, NY: SUNY Press.

Walker, D. (2003). Fundamentals of Curriculum: Passion and Professionalism (2nd ed.). Mahwah, NJ: Lawrence Erlbaum.

Wei, R. C., Darling-Hammond, L., \& Adamson, F. (2010). Professional Development in the United States: Trends and Challenges. Dallas, TX: National Staff Development Council.

Wiggins, G., \& McTighe, J. (1998). Understanding by Design. Alexandria, VA: Association for Supervision and Curriculum Development. 